\title{
Evaluation of Echocardigraphic Parameters in Patients with Rhythm Disorders Associated with Chronic Hepatic Diseases
}

\author{
VERONICA CALBOREAN ${ }^{1}$, ION UDRISTOIU2*, ANDREEA DENISA DOCEA ${ }^{3}$, MIHAI CRISTIAN HODOROG ${ }^{4}$, \\ SORIN NICOLAE DINESCU5, OANA CRICIOTOIU6, DIANA STANCA6, ADRIAN MITA7, DRAGOS VIRGIL DAVITOIU ${ }^{8}$, \\ VLAD DUMITRU BALEANU ${ }^{9}$, FLORIN MARIUS ROMANESCU ${ }^{10}$, MARIUS BICA ${ }^{11}$, CECIL SORIN MIREA $^{11}$, \\ VENERA CRISTINA DINESCU12 \\ IUniversity of Medicine and Pharmacy of Craiova, Cardiology Department, 2 Petru Rares Str., 200349, Craiova, Romania \\ 2University of Medicine and Pharmacy of Craiova, Psychiatry Department, Neuropsychiatry Hospital of Craiova, 24 Aleea Potelu \\ Str., 200473, Craiova, Romania
}

\begin{abstract}
${ }^{3}$ University of Medicine and Pharmacy of Craiova, Gynecology Department, 2 Petru Rares Str., 200349, Craiova, Romania ${ }^{4}$ University of Medicine and Pharmacy of Craiova, Department of Urology, 2 Petru Rares Str., 200349, Craiova, Romania 5University of Medicine and Pharmacy of Craiova, Epidemiology and Primary Health Care Department, 2 Petru Rares Str.,200349, Craiova, Romania

${ }^{6}$ University of Medicine and Pharmacy of Craiova, Neurology Department, Neuropsychiatry Hospital of Craiova, 99 Calea Bucuresti Str., 200473, Craiova, Romania

University of Medicine and Pharmacy of Craiova, Internal Medicine Department, Filantropia Hospital of Craiova,1Filantropiei Str., 200143, Craiova, Romania

¿University of Medicine and Pharmacy of Bucharest, Surgery Department, Clinical Emergency Hospital Sf. Pantelimon Bucharest, 340-343 Pantelimon Road, 021659, Bucharest, Romania

'University of Medicine and Pharmacy of Craiova, Surgery Department, Clinical Emergency Hospital Sf. Pantelimon Bucharest, 340-343 Pantelimon Road, 021659, Bucharest, Romania

10University of Medicine and Pharmacy of Craiova, Department of Physiology, 2 Petru Rares Str., 200349, Craiova, Romania ${ }^{11}$ University of Medicine and Pharmacy of Craiova, Surgery Department, 2 Petru Rares Str., 200349, Craiova, Romania 12University of Medicine and Pharmacy of Craiova, Health Promotion and Ocupational Medicine Department, 2 Petru RaresStr., 200349, Craiova, Romania
\end{abstract}

Due to the increased frequency of cardiovascular diseases in the evolution of chronic liver disease, we proposed to assess echocardiographic changes in patients with rhythm disorders associated with chronic liver disease. To analyze the degree of cardiac damage, each patient was subjected to a complete cardiovascular examination.

Keywords: hepatic disease, echocardiographic examination, cardiac affectation

Rhythm disorders refer to the abnormality or disturbance of the normal myocardial activation sequence [1-6]. This indicate structural cardiac disease and may be the cause of significant cardiovascular complications and sudden cardiac death [5-11].

Regardless of its etiology spectrum, the hepatic disease leads changes in the structure and functions of the heart, mostly with latent, infra-clinically progression, often recognized by clinicians with difficulty [12-15].

Cardiovascular diseases are one of the leading causes of death in the world[16-17]. Rhythm disordes are associated with increased morbidity and mortality [18-19]. The association between chronic hepatic disease and rhythm disorders cause additional comorbidities [20-24]. Early recognition of the underlying causes of cardiovascular disease, of the clinical and para-clinical test and the modifiable risk factors, determine its rate of progression and focus on preventive treatment and possible complications of the chronic hepatic disease [21-24].

The diversity of the etiological factors of chronic liver disease involves investigating each aspect of the arrhythmogenic substrate and assessing its triggering and aggravating factors in order to obtain a diagnosis of high probability and practical utility.

\section{Experimental part}

The aim of the study

In our study, 126 patients were diagnosed based on the clinical and para-clinical tests with chronic hepatic disease and 120 patients withoutchronic liver disease, representing the control group.

The study was conducted over a period of 14 months, from 1.10 .2016 to 1.01 .2018

The purpose of our study was to assess the echocardiographic parameters in patients with rhythm disorders associated with chronic hepatic disease.

We have correlated different signs of cardiac damage, those characteristic of systolic and diastolic dysfunction with the etiology of chronic liver disease.

To analyze the degree of cardiac damage, each subject in our research (study lot plus control lot) was subjected to a complete cardiovascular examination:

- Anamnesis and clinical examination of the cardiovascular system, with evaluation of positive signs and symptoms, specific to heart disease

- Echocardiography for the evaluation of cardiac changes. We studied left ventricular function, left ventricular diameters both in systole and diastole, left ventricular posterior wall, right ventricle, right atrium, left atrium, and interventricular septum.

\section{Results and discussions}

The echocardiographic examination was influenced by a number of factors. These include obesity, pulmonary emphysema, altered somatic status, psychomotor restlessness and agitation so frequently encountered in patients with cardiac impairment [25]. 
We have noticed a series of correlations between various morphological and functional cardiac changes and comorbid hepatic pathology. These data are consistent with the literature that states that both diastolic and systolic function are altered in liver cirrhosis [18]. These changes in ventricular function are accentuated under stress conditions [3,23-24]. Some studies show that diastolic dysfunction is presentin all patients diagnosed with chronic liver disease[26]. Although these morphological changes are not in a relationship of direct proportionality with diastolic dysfunction, we consider that echocardiography plays a fundamental role in the early detection of systolic and diastolic dysfunctions [26].

We have granted great importance to the analysis of the left atrium diameter since changes to it may bring alarm signals for the installation of severe heart disease.

It is known that the diameter of the left atrium is a marker of diastolic dysfunction. It is also known that many markers of diastolic failure normalize with the adjustment of the filling pressure, while the left atrium diameter remains a long time increased [27-29] (fig. 1).

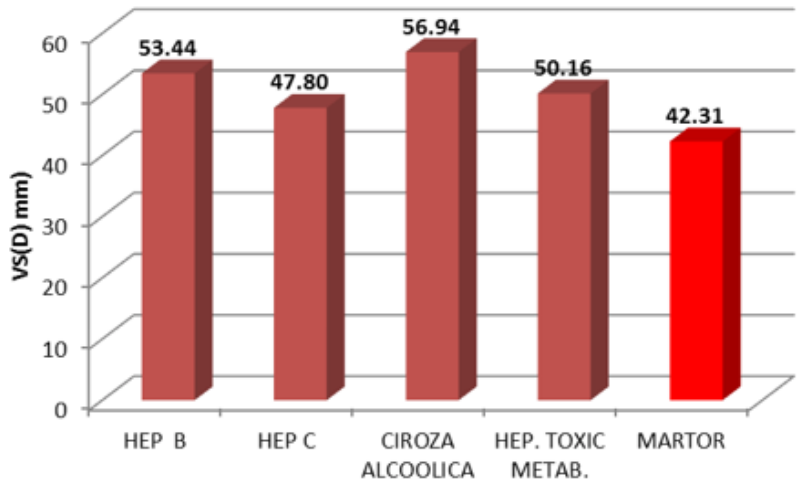

Fig. 1. Echocardiographic analysis of left ventricle in diastole. Correlations with the etiology of liver disease

The mean VS (D) diameter in patients with chronic hepatic disease, depending on etiology, was $53.44 \mathrm{~mm}$ for patients diagnosed with chronic viral hepatitis $B, 47.8 \mathrm{~mm}$ for subjects with chronic viral hepatitis C, 56.94 for patients diagnosed with alcoholic cirrhosis and $50.16 \mathrm{~mm}$ for patients with toxic-metabolic hepatitis. The mean VS (D) for the control group was $42.31 \mathrm{~mm}$.

Comparing the mean value of VS (D) according to liver disease etiology with the mean value of the control group, we noticed a significant difference using the Student t test (Student $\mathrm{t}$ test $<0.0001$ ).

This markedly significant difference was recorded to all of the patients with liver disease from our study group ( fig. 2).

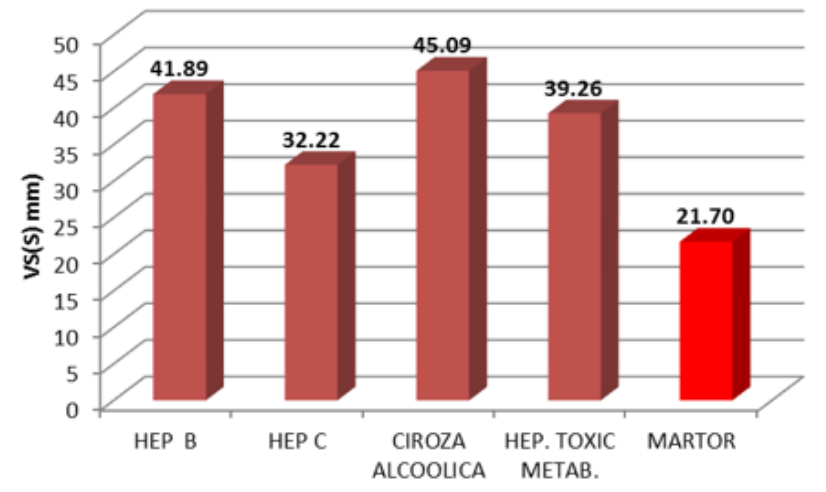

Fig. 2. Echocardiographic analysis of left ventricle in systole. Correlations with the etiology of liver disease.
Analyzing the mean as a statistical indicator, we obtained the following results: 41.89 - mean for chronic viral hepatitis B, 32.22 for chronic viral hepatitis C, 45.09 for patients with al coholic cirrhosis and 39.26 for patients with metabolic toxic hepatitis .

It should be noted that the mean of the control group registered the value of $21.7 \mathrm{~mm}$, as it can be seen a much lower value than those recorded in the patients from the study group.

The significant difference from the control group was high. This was also confirmed by the results of the Student t test $(p<0.0001)$ (fig. 3).

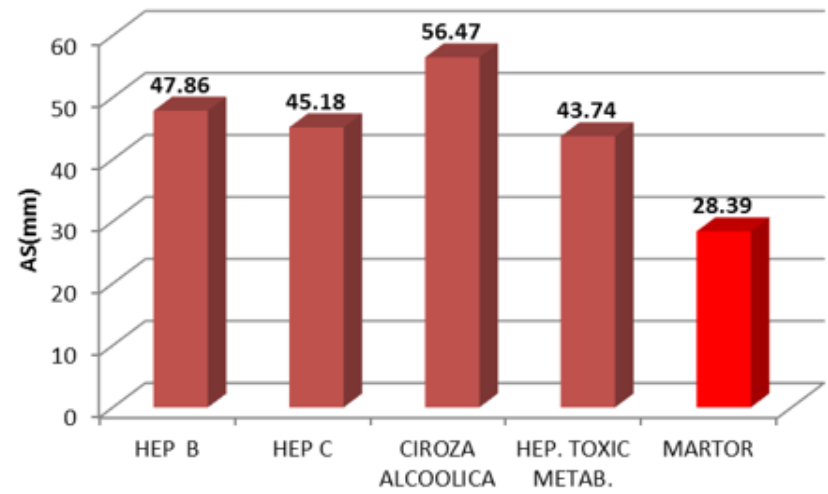

Fig. 3. Echocardiographic analysis of left atrium (AS). Correlations with the etiology of liver disease

We obtained the following mean values of left atrium: $47.86 \mathrm{~mm}$ for patients with chronic viral hepatitis $B, 45.18$ $\mathrm{mm}$ for patients with chronic viral hepatitis $C, 56.47 \mathrm{~mm}$ for patients with alcoholic cirrhosis and $43.74 \mathrm{~mm}$ for the diagnosed subjects with metabolic toxic hepatitis.

The analysis with the control group shows significant differences both by comparing the recorded value from the control group $(28.39 \mathrm{~mm})$ vs the mean value of the study group $(48.83 \mathrm{~mm})$ and through the results of the Student test $(P<0.0001)$ (fig. 4).

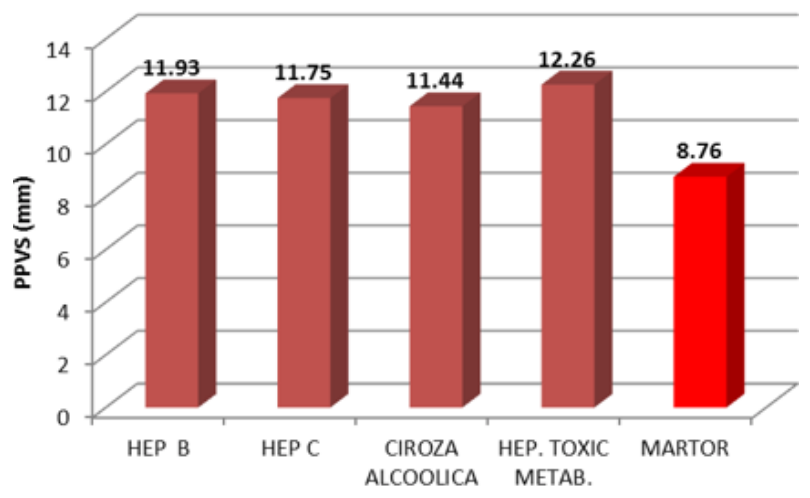

Fig. 4. Echocardiographic analysis of left ventricular posterior wall (PPVS). Correlations with the etiology of liver disease

The mean value of the left ventricular posterior wall relative to the entire nostologic palette of our research was $11.80 \mathrm{~mm}$. It was divided into etiologies as follows: 11.93 $\mathrm{mm}$ - chronic viral hepatitis $B, 11.75 \mathrm{~mm}$ - chronic viral hepatitis C, $11.44 \mathrm{~mm}$ - alcoholic cirrhosis and $12.26 \mathrm{~mm}$ metabolic toxic hepatitis.

The left ventricular posterior wall mean for the control group was $8.76 \mathrm{~mm}$. This clear difference between the study group and the control group is also reinforced by the statistical analysis where the $p$ value of the Student test is less than 0.0001 (fig. 5). 


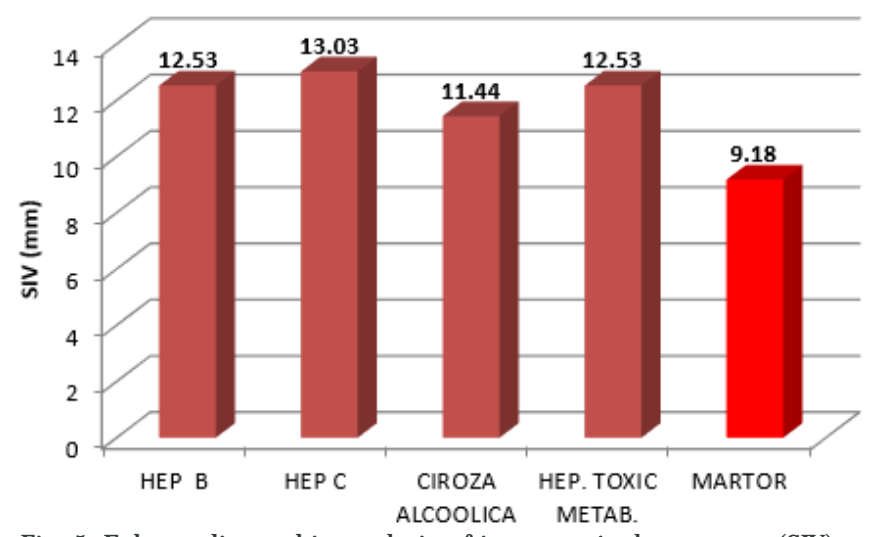

Fig. 5. Echocardiographic analysis of interventricular septum (SIV). Correlations with the etiology of liver disease

Interventricular septum mean values had the following data: $12.53 \mathrm{~mm}$ for chronic viral hepatitis $B, 13.03 \mathrm{~mm}$ for chronic viral hepatitis C, $11.44 \mathrm{~mm}$ for alcoholic cirrhosis, and 12.53 for metabolic toxic hepatitis.

The total diameter mean value of the interventricular septum for the study group is $12.37 \mathrm{~mm}$, while the total mean of the interventricular septum for the control group is $9.18 \mathrm{~mm}$.

This significant difference is also statistically confirmed by the Student t test ( $p<0.0001$ )(fig. 6).

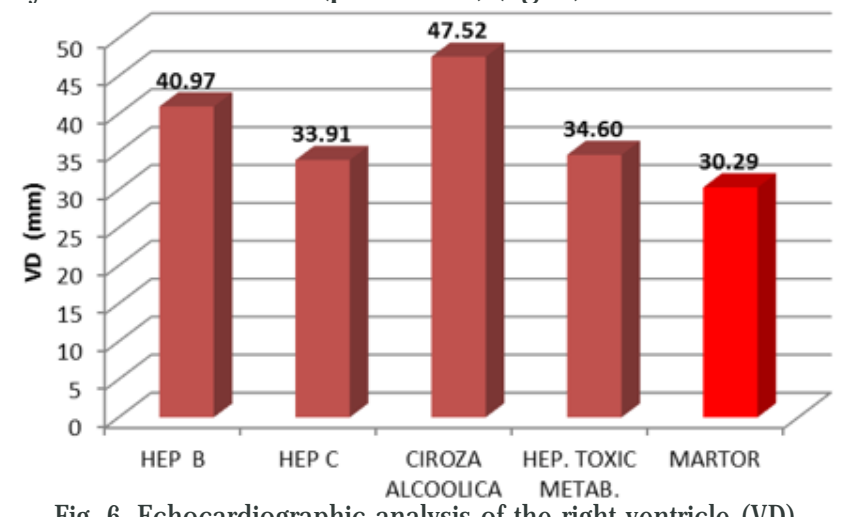

Fig. 6. Echocardiographic analysis of the right ventricle (VD) Correlations with the etiology of liver disease

The mean VD diameter for patients with chronic viral hepatitis B was $40.97 \mathrm{~mm}$, for those with chronic viral hepatitis C $33.91 \mathrm{~mm}, 47.52 \mathrm{~mm}$ for patients with alcoholic cirrhosis and $34.60 \mathrm{~mm}$ for those with metabolic toxic hepatitis. We note, therefore, an average of $39.97 \mathrm{~mm}$ for patients from the study group versus an average of 30.29 $\mathrm{mm}$ for patients from the control group.

The Studentttest shows significant differences between the ventricular diameter value for the study lot/ control lot on the following pathologies: chronic viral hepatitis $B$, chronic viral hepatitis $\mathrm{C}$ and alcoholic cirrhosis. Regarding metabolic toxic hepatitis, there were no significant differences from the control group ( $p=0.119$ ) (fig. 7).

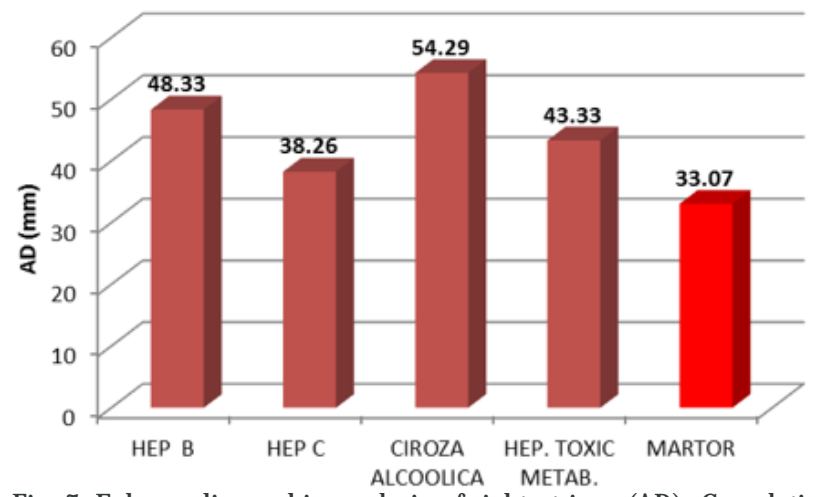

Fig. 7. Echocardiographic analysis of right atrium (AD). Correlations with the etiology of liver disease
The mean of the studied lot showed a total value of the right atrium of $46.54 \mathrm{~mm}$.

For patients with chronic viral hepatitis B was $48.33 \mathrm{~mm}$, for those diagnosed with chronic viral hepatitis $\mathrm{C}$ the value was $38.26 \mathrm{~mm}, 54.29 \mathrm{~mm}$ for patients with alcoholic cirrhosis and $43.33 \mathrm{~mm}$ for those with metabolic toxic hepatitis.

The mean for the control lot regarding right atrium diameter was $33.07 \mathrm{~mm}$.

The Student $t$ test recorded significant differences ( $t$ Student test $<0.0001$ ) for all the hepatic etiologies from the subjects in our group (viral, alcoholic and metabolic toxic etiology) (fig. 8).

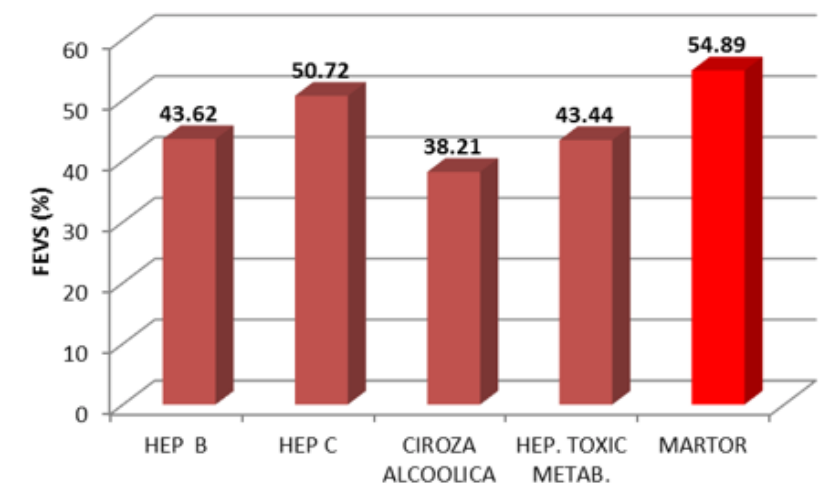

Fig. 8. Echocardiographic analysis of left ventricular ejection fraction (FEVS). Correlations with the etiology of liver disease

The mean of left ventricular ejection fraction in our patients from the study group it was different according to the etiology of hepatic disease. In patients with alcoholic cirrhosis it was $38.21 \%$, in those with metabolic toxic hepatitis $43.44 \%$, in those with chronic viral hepatitis B $43.62 \%$ and the highest mean was recorded in patients with chronic viral hepatitis C ( $50.72 \%)$.

The total average of left ventricular ejection fraction was $43.97 \%$, much lower than the control group (54.89\%).

This significant difference is confirmed by the Studentt test ( $p<0.0001)$ (fig. 9).

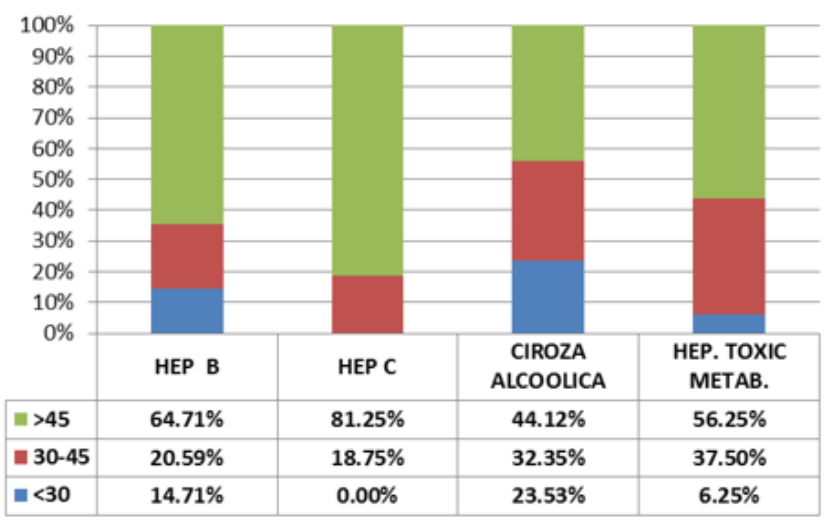

Fig. 9

We divided the group into three categories according to the left ventricular ejection fraction, namely: the first category included patients with left ventricular ejection fraction of less than $30 \%$, the second category had targeded subjects with FEVS between 30 and $45 \%$ and the third category included patients with a left ventricular ejection fraction greater than $45 \%$.

As can be seen from the graph above, most patients with FEVS below $30 \%$ were those diagnosed with alcoholic cirrhosis. On the second place were patients diagnosed with chronic viral hepatitis $B$.

A percentage of $6.25 \%$ of patients with metabolic toxic hepatitis had FEVS $<30 \%$. None of the patients diagnosed 
with chronic viral hepatitis $\mathrm{C}$ had a left ventricular ejection fraction less than $30 \%$.

Analyzing the $30-45 \%$ interval of left ventricular ejection fraction we can see that the highest percentage is recorded in the diagnostic group with metabolic toxic hepatitis (37.50\%). On the second place are subjects diagnosed with alcoholic cirrhosis, where over $32 \%$ of the patients suffering from this pathology recorded FEVS values between $30-45 \%$. With FEVS between $30-45 \%$ were fewer subjects diagnosed with chronic viral hepatic disease ( $20.59 \%$ of patients with chronic viral hepatitis B and $18.75 \%$ patients with chronic viral hepatitis C).

The best results of the left ventricular ejection fraction were recorded in patients diagnosed with chronic viral hepatitis C. Over $81 \%$ of these patients had values of FEVS above $45 \%$.

\section{Conclusions}

Echocardiography is a simple and non-invasive method, but extremely useful for preventing severe heart disease.

All of our correlations were reinforced by statistically significant differences between the study group and the control group, confirmed by the mean study, the standard deviation and the Student test.

\section{References}

1.FORTOFOIU, M., FORTOFOIU, M.C., COMANESCU, V., DOBRINESCU, A.C., PADUREANU, V., VERE, C.C., STREBA, C.T., CIUREA, P.L. Rom J Morphol Embryol 2015, vol 56, p. 1461-1465.

2.CALBOREAN, V., CIOBANU, D., MIREA, S.C., GALCEAVA, O.,GHEORMAN, V., PADUREANU, V., FORTOFOIU, C.M., FORTOFOIU,M., MITA, A., DINESCU, S.N., MISCOCI, S.A., DINESCU, V.C., Rev. Chim. (Bucharest), 69, nr. 9, 2018, p.2744-2748.

3.GHEORMAN, V., MILITARU, F., CALBOREAN,V., GHEORMAN, L.M.,CHIRITA, A.L., MITA, A., GALCEAVA, O., GHEORMAN, V., STANCA, D.,UDRISTOIU, I., Rev. Chim. (Bucharest), 69, no. 4, 2018, p.881-885. 4.GHEORMAN,V.,CHIRITA,A.L.,DUMITRESCU,E.M.,ROGOVEANU,I., ISTRATOAIE,O., GHEORMAN,V.,PANA,R.C. Rom J Morphol Embryol, 2016, 57(1): 45-50.

5.CALBOREAN,V., GHEORMAN,V., DINESCU,S.N., STANCA,D., GALCEAVA,O., FORTOFOIU,M., MITA,A., MIHAILOVICI,A.R., MISCOCI,S.A.,BALEANU,V.D., DINESCU, V.C., Rev. Chim. (Bucharest), 69, no. 11, 2018, p.4237- 4240

6.PETRESCU, F., PETRESCU, O.I., TAISESCU, C.I, COMANESCU, M.V., FORTOFOIU, M.C., PREDESCU, I.O., ROSU, A.F., GHEONEA, C., BICIUSCA, V. Rom J Morphol Embryol , 2015, vol 56, p. 439-444.

7.CALBOREAN, V., GHEORMAN, V., OCTAVIAN, I., MUSTAFA, R.E.,COJ OCARU, P.A., ALEXANDRU, D.O., GALCEAVA, O., MITA, A.,MISCOCI, S.A., AL NAMAT, R., GHEONEA,D.I. Rev. Chim. (Bucharest), 69, no. 5, 2018, p.1134-1138.

8.MESINA, C., VASILE, I., VILCEA, I. D., PASALEGA, M., CALOTA, F., PARVANESCU, H., DUMITRESCU, T., MIREA, C., MOGOANTA, $S$. Chirurgia, nr. 3, Vol. 108, 2013, p. 400-406.

9.PASALEGA, M., MIREA, C., VILCEA, I. D., VASILE, I., PLESEA, E., CALOTA, F., MESINA, C., PARVANESCU, H., BALUTA, M. Romanian Journal of Morphology and Embriology, nr. S1, Vol. 52, 2011, p. 503508.

10. MESINA, C., VASILE, I., VILCEA I. D., PASALEGA, M., PARVANESCU, H., CALOTA, F., GEORGESCU, C.V., GHILUSI, M., DUMITRESCU, T., MIREA, C., MOGOANTA, S., MORARU, E. Chirurgia, nr. 2, Vol. 105, 2010, p. 257-266.
11.CIOBANU, D., MESINA, C., STREBA, L., GRUIA, C.L., DITESCU D., SARLA C. G, ENESCU, A., PETRESCU, F. Rom J Morphol Embryol 2014, vol 55 (3 Suppl).

12.CALBOREAN, V., MISCOCI, S. A., ISTRATOAIE, O., GALCEAVA , O.,ALEXANDRU, D.O., GUTA, M.M., GHEORMAN, V., PADUREANU,V., FORTOFOIU, C.M., DIJ MARESCU, A.L., GHEONEA, D.I. Rev Chim (Bucharest), 69, no. 6, 2018, p. 1527-1532.

13.PUIU,I,ALBU,C.V., TARTEA,E.A., CALBOREAN,V., GHEORMAN,V., DINESCU,S.N., VASILE,R.C., DINESCU,V.C., BICA, E.C., ROMANESCU, F.M., TUDORASCU,D.R. Rev Chim (Bucharest), 69, no. 10, 2018, p. 2744-2748.

14.ENE,C.G.,ROSU,A., GHEORMAN,V., CALBOREAN,V., TENEA COJAN,T.S., ROGOVEANU,O.C., VLADU,M.I., RADU, L. Rev Chim., (Bucharest), 69, no. 7, 2018, p.1851-1854.

15. VLADU, I.M., RADU, L., GIRGAVU, S.R., TENEA COJAN, T.S., ENE, C.G., CALBOREAN, V., GHEORMAN,V., CLENCIU ,D. Rev. Chim., (Bucharest), 69, no. 9, 2018, p.2479-2481.

16.CALBOREAN,V., GHEORMAN,V., AL NAMAT, R., CAZACU,I. M., VARJU,P., GEDE, N., STREBA,T.C., VERE, C.C., GHEONEA,D.I., GHEORMAN, V., LUNGULESCU, C., LUNGULESCU, C.,V. Rev. Chim. (Bucharest), 68, no. 12, 2017, p.3010-3014

17.MIHAILOVICI, A.R., PADUREANU,V., ALBU, C.V. DINESCU, V.C., PIRLOG, M.C., DINESCU, S.N., MALIN, R.D., CALBOREAN, V., Rev. Chim. (Bucharest), 69, no. 8, 2018, p 2209-2212.

18.CORICI, O. A., TANASIE, C.A., ALEXANDRU, D.O., FLORESCU, C.M,COMANESCU, M.V., KAMAL, C., TENEA-COJ AN, T.S, IANCAU, M.,DINESCU, S.N. Rom J MorpholEmbryol;2018,59(1):93-103.

19.BALEANU, V.D. , CONSTANTIN, D.V ., PASCAL, A ., ALEXANDRU, D.O., BOBIC, S., SOCEA, B ., MANDA, A.L., DAVITOIU, D.; DIJ MARESCU, A.L., GEORGESCU, I., MIREA, C.S. Rev Chim (Bucharest), 69, no. 7, 2018, p 1740-1743.

20.NOVAC, M.V., NICULESCU, M., MANOLEA, M.M., DIJ MARESCU, A.L., ILIESCU, D.G., NOVAC,M.B., ROTARU,L.T, STOENESCU, M.F., TABACU, M.C., TUDORACHE, S., BUSUIOC, C.J. , GHEONEA, I.A. Rom J Morphol Embryol , 2018, vol 59, p. 715-720.

21.STOENESCU,V.E., NICULESCU, M., NOVAC, L., MANOLEA, M.M., TOMESCU, P.I., DIJMARESCU, A.L., NOVAC, M.B., TUDORACHE, S., ILIESCU, D.G. Rom J Morphol Embryol , 2017, vol 58, p. 791-800. 22.SIMINEL,M.A., GHEONEA,C., STANESCU,M.R., COMANESCU, A.C., DIJ MARESCU, A.L., NEAMTU, S.D., COTOI, B.V., NEDELCUTA, R.M., NICULESCU, E.C. Rom J Morphol Embryol , 2015, vol 56, p.301308.

23.BUICU, G.E., GRECU, M.G., SALCUDEAN, A., GRECU, I.G., MARINESCU, C., NIRESTEAN, A., TURLIUC, S., HADAREANU, V., UDRISTOIU, I. EUROPEAN PSYCHIATRY, 41, 2017, p. S583-S584.

24.CHIMORGIACHIS, A., COSNTANTIN, M.D.G., UDRISTOIU,T., PIRLOG, M.C.,UDRISTOIU, I. JOURNAL OF NEURAL TRANSMISSION, 114, issue 7, 2007, p. CXX-CXX.

25.NAGATA, Y., KADO, Y., ONOUE, T., etal. Echo Research and Practice. 2018;5(1):27-39.

26. SAMPAIO, F., PIMENTA, J., BETTENCOURT, N., FONTESCARVALHO, R., SILVA, A.P., VALENTE, J., BETTENCOURT, P., FRAGA, J ., GAMA, V. Liver Int. 2013 Sep;33(8):1158-65.

27. LI, X., YU, S., LI, L., HAN, D., DAI, S., \& GAO, Y. (2014). International Journal of Clinical and Experimental Medicine, 7(12), p.5751-5757. 28.TRASCA, S.P., FLORESCU, C., DINESCU, V.C.,PUIU, I., DINESCU, S.N., TUDORASCU, D.R., BICA, C., VASILE, R.C., ROMANESCU, F.M., BUNESCU, M.G., CIOATERA, N., GOANTA, E.V., Rev. Chim. (Bucharest), 2018, 69, no.12, p.3600-3604.

29.CALBOREAN, V., GHEORMAN, V.,CONSTANTIN, C., ISTRATOAIE, 0.J ournal of Cardiovascular Emergencies, 2018, 4, nr.2, p. 101-105 